\title{
The Occupational Safety of Health Professionals Working at Community and Family Health Centers
}

\author{
Havva Ozturk ${ }^{1, *} ;$ Elif Babacan ${ }^{2}$ \\ ${ }^{1}$ Faculty of Health Sciences, Karadeniz Technical University, Trabzon, Turkey \\ ${ }^{2}$ Education Unit, General Secretariat of the Association of Public Hospitals in Trabzon, Trabzon, Turkey \\ ${ }^{*}$ Corresponding Author: Havva Ozturk, Faculty of Health Sciences, Karadeniz Technical University, Post Code: 61080, Trabzon, Turkey. Tel: +90-4622300476, Fax: $+90-4622300475$, \\ E-mail: ozturkhavva@gmail.com
}

Received: November 23, 2013; Revised: April 13, 2014; Accepted: April 27, 2014

\begin{abstract}
Background: Healthcare professionals encounter many medical risks while providing healthcare services to individuals and the community. Thus, occupational safety studies are very important in health care organizations. They involve studies performed to establish legal, technical, and medical measures that must be taken to prevent employees from sustaining physical or mental damage because of work hazards.

Objectives:This study was conducted to determine if the occupational safety of health personnel at community and family health centers (CHC and FHC) has been achieved.

Martialsand Methods: The population of this cross-sectional studycomprised 507 nurses,199 physicians, and 237 other medical personnel working at a total of 18 family health centers (FHC) and community health centers (CHC) in Trabzon, Turkey. The sample consisted of a total of 418 nurses, 156 physicians, and 123 other medical personnel.Sampling method was not used, and the researchers tried to reach the whole population. Data were gathered with the Occupational Safety Scale(OSS) and a questionnaire regarding demographic characteristics and occupational safety.

Results: According to the evaluations of all the medical personnel, the mean \pm SD of total score of the OSS was 3.57 \pm 0.98 ; of the OSS's subscales, the mean \pm SD of the health screening and registry systems was $2.76 \pm 1.44$, of occupational diseases and problems was $3.04 \pm 1.3$ and critical fields control was $3.12 \pm 1.62$. In addition, occupational safety was found more insufficient by nurses $(\mathrm{F}=14.18 ; \mathrm{P}<0.001)$.

Conclusions: All healthcare personnel, particularly nurses working in CHCs and FHCs found occupational safety to be insufficient as related to protective and supportive activities.
\end{abstract}

Keywords:Occupational Safety; Community Health; Family Health; Health Personnel

\section{Background}

The last two decades have been subject to an increase in social awareness regarding the rights of all workers about workplace health and safety. The laws and regulations in this area were established to protect workers and increase their welfare in the workplace. Irrespective of the context of the work environment, the importance of ensuring workplace health and safety for all is now a reality (1). This fact is valid for the health sector as well, because the field of healthcare services is one of the sectors carrying significant risks in terms of occupational health and safety. For example, the injury rate of healthcare workers in this sector is equal to or higher than the rates in other industries that are traditionally considered hazardous (2).

In Turkey, the number of medical staff working at healthcare organizations is around 389,000 and 63\% of this workforce is employed by the Ministry of Health. Of these, approximately 13,000 physicians, 11,000 nurses, and 19,000 midwives work at community health centers, and 5000 physicians, 3000 nurses and 6000 midwives work at family health centers (3). Health personnel employed at these centers face various risk factors while offering health services to families and the community (4). The hazards or threats in these working environments are classified as biological (e.g. viruses, fungi), physical (e.g. needle sticking, loud noises), ergonomic (e.g. pain in the lower back and extremities), chemical (e.g. disinfectants, germicides), and psychological risks (e.g. stress, violence). Furthermore, these hazards and risks increase occupational accidents and diseases, jobrelated health problems, and disabled and incapacitated employees, thus generating new and different problems. They also reduce job performance, which in turn, generates economic loss for healthcare organizations (5). A study conducted at community health centers indicated that 9 out of 10 personnel were exposed to at least one kind of occupational risk (6). Violence, periods of acute or chronic pain, sharp object injuries, chemical matter spillage, animal attacks, and heat stroke were identified as the most frequently encountered problems in the 
same study (6). Moreover, some studies stated that occupations in the health and community services such as nursing, social work, medicine, rehabilitation work, and welfare are widely regarded as stressful (7-9), and that work-related stress is a significant risk factor for physical health, causing for instance, cardiovascular diseases in addition to psychological disorders like depression (9, 10). A study conducted regarding risk perception in family health work also indicated that healthcare personnel identified the following risks: physical and moral violence, emotional exhaustion, typical work accidents, lack of problem-solving ability, and occupational diseases (11). A study on workplace injuries at nursing homes showed that 13.5 per 100 workers needed medical treatment or experienced lost work (12), and there were 139,700 lost workdays as a result of injuries (13). In addition, there are studies indicating that the costs of occupational injuries and illnesses in health services are high (14).

Besides these results, it was determined that the working environment and conditions negatively affect the occupational safety of the staff such as physicians, nurses, midwives, and laboratory technicians working at those centers (4). However, the correlation between the working life and health of medical staff working in primary healthcare centers has been demonstrated; therefore, identifying the risks associated with the health and safety of medical staff and launching initiatives regarding occupational safety should be obligatory. It has also been mentioned that there is a limited number of studies in this field (6). After the recognition of the importance of this issue in Turkey, a declaration was promulgated in 2009 for the provision and protection of patient and personnel safety in healthcare organizations, including community and family health centers (15). All these studies have demonstrated that the occupational safety of the medical workforce employed at community and family health centers as well as in the whole field of healthcare should be ensured.

In this respect, this study may enable us to determine the frequent hazards and risks encountered at these centers and take necessary preventive measures. Inadequate and incomplete activities in terms of work safety may be identified too. Thereby, a contribution was made to reduce occupational accidents or diseases and to prevent workforce losses in the health sector as well as the social and familial problems that occur because of these losses. The safety of patients may be secured through the safe, restful, happy, and satisfied work of the staff. The costs of the hazards and damages brought forward by the lack of work safety may be diminished in these centers.

\section{Objectives}

This study was conducted to determine whether the occupational safety of nurses, physicians, and other healthcare personnel employed at family and community health centers (FHCs and CHCs) in Trabzon/Turkey had been achieved.

\section{Materials and Methods}

This research was a cross-sectional study that was conducted from February $1^{\text {st }}$ to $26^{\text {th }}, 2010$. The population of the study comprised 507 nurses, 199 physicians, and 237 other healthcare personnel working at a total of 18 FHCs and CHCs affiliated with the Ministry of Health in Trabzon, Turkey. The sample of the study consisted of a total of 418 nurses, 156 physicians and 123 other healthcare personnel. No sampling method was used, and the researchers tried to reach the whole population. At the same time, 223 healthcare personnel who were on leave for any reason or were unwilling to participate were excluded from the study. In addition, 23 healthcare personnel who had failed to complete or incorrectly completed the data collection instruments were excluded from the research.

In terms of ethical considerations, the study was conducted in all FHCs and CHCs of the Directorate after written permission had been obtained from the Provincial Health Directorate affiliated with the Ministry of Health in Trabzon, Turkey on December 31, 2010. In addition, the data collection forms were filled out by volunteering health staff whose informed consent to participate in the study had already been obtained. Furthermore, this study did not encounter any conflict or potential conflict. All data and tables, the scale and questionnaire used in the study, were originally prepared by the authors of the study. The fact that the data collection tools were the work of the researchers and no conflict had been encountered is one of the strengths of the research. Another strong point is that the study was conducted with a large sample group that encompassed the entire province of Trabzon. A limitation of the study was that it relied solely on the opinions of nurses, doctors and other healthcare professionals who volunteered to participate or who were working at the FHCs and CHCs within the boundaries of the province of Trabzon.

Data were collected with a survey, containing 6 questions related to demographic characteristics (age, gender, marital status, educational background, occupation and work experience at the hospital), and 6 questions related to occupational safety (level of satisfaction from occupational health implementations, the frequency of occupational accidents and diseases at the center, the state of exposure to occupational accidents and occupational diseases, being informed of the communiqué on patient and personnel safety), accompanied by an occupational safety scale (OSS) consisting of 42 items, developed by Ozturk et al. (16). The researchers distributed and collected the data collection instruments by hand among the healthcare personnel working at the FHCs and CHCs.

The OSS consisted of 42 items and intended to determine whether the occupational safety of health personnel or worker safety in the family and community health centers, as well as the activities carried out for occupational safety, have been achieved. It is assessed on a scale from 6 (I completely agree) to 1 (I completely disagree). In 


\section{Ozturk Het al.}

the evaluation of the scale, the total score of the scale is proportional to the total number of items, whereas the subscale scores are proportional to the number of items on the subscale; testing and interpretation is carried out afterwards (Table 1). Accordingly, receiving more than 3.5 points on an average from the scale shows that occupational safety prevails at family and community health centers; obtaining less than 3.5 points on average means that occupational safety is not sufficient.

There are 7 subscales of the OSS that have been categorized as "Occupational Diseases and Complaints" (S1), "Injuries and Poisoning" (S2), "Health Screening and Registry Systems" (S3), "Material, Tools and Equipment Control" (S4), "Physical Medium Compatibility" (S5), "Critical Fields Control" (S6), and "Instructions and Rules" (S7) (Table 1).

The scale is a reliable and valid instrument (16). Surface validity, content validity, and construct validity with explanatory factor analysis were tested for the validity of the scale. Item-total correlation and Cronbach $\alpha$ tests were used to test the reliability of the scale (Table 1) (16). In this process, first of all, the draft scale consisting of the 75 items was formed by the researchers based on the literature review. It was then evaluated by four colleagues/ health personnel to test its surface validity, a process that was performed to assess the understandability and length of items. Surface validity was ensured by the revision of 5 items (17). Afterwards, the draft scale was presented to five experts in occupational safety to test for both surface validity and content validity. By scoring each item between 1 and 4 ( 1 = not appropriate, $2=$ should be revised, $3=$ appropriate but needs minor changes, $4=$ appropriate), the experts evaluated the suitability of items to purpose or conceptual structure and whether the items were stated in a correct, clear and explicit form (Sencan, 2005). None of the items were removed from the scale.

However, 16 items, which were not comprehensible, were optimized. As a result, the content validity index (CVI) of the draft scale was \%92 (16). Explanatory factor analysis was conducted for construct validity with the Kaiser-Meyer-Olkin (KMO), Bartlett test, anti-image correlation, principal component analysis, and Varimax Rotation tests. The KMO test, which shows whether a given sample is sufficient for factor analysis, was 0.93; the Bartlett test, which shows whether there is a sufficient relationship between the variables, was found to be $\chi^{2}=$ 1.935; $\mathrm{P}<0.001$ (18). Anti-image correlation values, which test the suitability of each item to factor analysis, ranged from 0.97 to 0.83 . The high values of KMO and anti-image as well as significance of the Bartlett test indicated that factor analysis could be carried out (18-20). Subsequently, Varimax rotation was used to determine the construct validity. Following the rated component matrix, 33 items with a subscale/component load of below 0.50 were omitted $(18,19)$. Therefore, the scale finalized with 42 items and 7 subscales (19). This result was desirable in practice. Some researchers accept this ratio at 50\% minimum (20).
The results also supported the validity of the scale. In addition, Item to total score correlation values ranged from 0.38 to 0.67 , and the Cronbach $\alpha$ value was 0.94 (it was 0.94 for nurses, 0.96 for physicians, and 0.93 for the other healthcare personnel) (Table 1). The values obtained from these tests showed that none of the items would have to be removed from the draft scale and that the scale was found to be reliable (17-20).

In the evaluation of the data with the SPSS13.0 program, frequency, percentages, and averages, the KolmogorovSmirnov test for normality, t test, analysis of variance (ANOVA) for independency variables, homogeneity, and normality, Tukey and Scheffe as posttest, Kruskal-Wallis, Mann-Whitney U due to non-homogeneity or not distributing normally, Bonferroni correction for posttest were used to determine whether the occupational safety of nurses, physicians, and other healthcare personnel employed at family and community health centers had been achieved.

\section{Results}

Sixty percent of the healthcare personnel consisted of nurses, $22 \%$ of physicians, and $18 \%$ of other healthcare personnel such as x-ray, laboratory, community, and environmental health technicians. Seventy-nine percent of the nurses were female, $82 \%$ were married, and $43 \%$ had associate degrees; on average $\pm \mathrm{SD}$, they were $34.93 \pm 7.56$ years old, had $13.57 \pm 8.06$ years of professional experience, and 7.06 \pm 7.79 ) years of work experience at the institution. Seventy-two percent of the physicians were male, $87 \%$ were married, and $100 \%$ had bachelor's degrees; on average \pm SD, they were $40.27 \pm 6.10$ years old, had 15.47 \pm 6.01 years of professional experience, and $6.08 \pm 7.09$ years of work experience at the institution. Fifty-eight percent of the other health personnel were female, $73 \%$ were married, and $43 \%$ had graduated from a vocational high school of health; on average \pm SD, they were $35.04 \pm 8.58$ years old, had $12.29 \pm 7.86$ years of professional experience, and $8.8 \pm 7.41$ years of work experience at the institution.

According to the findings related to occupational safety, $73 \%$ of the nurses, $71 \%$ of the physicians, and $71 \%$ of other health personnel explained that they had not been aware of the "communiqué on patient and occupational safety." According to results of scale, all the healthcare personnel working at FHCs and CHCs evaluated the mean \pm SD of the total score of the scale as $3.57 \pm 0.98$. In addition, they evaluated mean \pm SD scores of the health screening and registry systems as $2.76 \pm 1.44$, occupational diseases and complaints $3.04 \pm 1.3$, and critical fields control $3.12 \pm 1.62$, which is lower than 3.5 when compared to the other subscales (Table 2).

Fifty one percent of the nurses, $63 \%$ of the physicians, and $47 \%$ of the other healthcare personnel stated that occupational injuries or accidents were rarely observed in their centers while $42 \%$ of the nurses, $45 \%$ of the physicians, and $32 \%$ of the other healthcare personnel stated that occupational diseases were rarely observed at their 
centers (Table 3). However, in terms of experienced occupational accident or injuries, $26 \%$ of the nurses indicated soft tissue trauma such as needle sticking and verbal violence from patient and relatives, whereas $21 \%$ of the physicians and $41 \%$ of other health personnel pointed to verbal violence; in addition, in terms of the experienced occupational diseases, $18 \%$ of the nurses and $17 \%$ of the physicians expressed digestive system diseases such as ulcers, colitis, while $36 \%$ of the other health personnel mentioned muscle-joint diseases such as disk hernia (Table 3 ).

Additionally, with respect to occupational safety at the center, $62 \%$ of the nurses were not satisfied with the undertaking and support of the institution in the event of an occupational accident or occupational disease, 61\% were not happy with the health and safety policies for the personnel, and $61 \%$ were unsatisfied with the occupational safety training provided (Table 4). Seventy-two percent of the physicians were not satisfied with the number of nurses, $62 \%$ with the undertaking and support of the institution in the event of an occupational accident or occupational disease, $60 \%$ with the occupational safety training provided. Furthermore, $67 \%$ of the other healthcare personnel were not satisfied with the undertaking and support of the institution in the event of an occupational accident or occupational disease, $65 \%$ were dissatisfied with personnel safety training, 59\% were unhappy with the quality of cleaning materials used (Table 4).
When the OSS and subscale scores were compared according to occupations, nurses found occupational safety more insufficient than physicians with regard to the total score of the OSS ( $\mathrm{F}=14.18, \mathrm{P}<0.001)$. According to the subscales, nurses found occupational safety more insufficient in terms of injuries and poisoning $\left(\chi^{2} \mathrm{~K}-\mathrm{W}\right.$ $=8.59, \mathrm{P}<0.05)$, health screening and registry systems $\left(\chi^{2} \mathrm{~K}-\mathrm{W}=8.99, \mathrm{P}<0.05\right)$, materials, tools, and equipment control $\left(\chi^{2} \mathrm{~K}-\mathrm{W}=16.14, \mathrm{P}<0.001\right)$ than physicians. On the other hand, nurses found occupational safety more insufficient than both physicians and other health personnel in the following subscales: occupational diseases and complaints $\left(\chi^{2} \mathrm{~K}-\mathrm{W}=17.31, \mathrm{P}<0.001\right)$, critical field's control $\left(\chi^{2} \mathrm{~K}-\mathrm{W}=24.33, \mathrm{P}<0.001\right)$, and protective instruction and rules $\left(\chi^{2} \mathrm{~K}-\mathrm{W}=16.41, \mathrm{P}<0.001\right)$. In addition, other health personnel found occupational safety more insufficient in materials, tools, and equipment control $\left(\chi^{2} \mathrm{~K}-\mathrm{W}=16.14, \mathrm{P}<\right.$ $0.001)$ and physical medium compatibility $\left(\chi^{2} \mathrm{~K}-\mathrm{W}=14.79\right.$, $\mathrm{P}<0.001$ ) than physicians (Table 5).

When compared to male nurses, female nurses thought that occupational safety was more insufficient in the following subscales: occupational diseases and complaints $(\mathrm{U}=8678, \mathrm{P}<0.001)$, injuries and poisoning $(\mathrm{U}=11130.5$, $\mathrm{P}<0.001)$, health screening and registry systems $(\mathrm{U}=$ 10932, $\mathrm{P}<0.001)$, critical fields control $(\mathrm{U}=12295.5, \mathrm{P}<$ $0.05)$, protective instruction and rules $(\mathrm{U}=12430.5, \mathrm{P}<$ $0.05)$, and in the total score of OSS $(\mathrm{t}=-4.495, \mathrm{P}<0.001)$.

Table 1. Cronbach $\alpha$ Values and Loads of Subscales of OSS

\begin{tabular}{lccc}
\hline Subscales & Number of Items & Cronbach $\alpha$ Values & Ranges of Subscale Loads \\
\hline S1. Occupational diseases and complaints & 15 & 0.942 & $0.783-0.540$ \\
S2. Injuries and poisoning & 6 & 0.924 & $0.863-0.541$ \\
\hline S3. Health screening and registry Systems & 6 & 0.881 & $0.807-0.665$ \\
S4. Material, tools, and equipment control & 5 & 0.850 & $0.781-0.688$ \\
S5. Physical medium compatibility & 4 & 0.779 & $0.771-0.688$ \\
S6. Critical fields control & 3 & 0.872 & $0.814-0.688$ \\
S7. Protective instructions and rules & 3 & 0.851 & $0.845-0.657$ \\
Total & 42 & 0.946 & $0.863-0.540$ \\
\hline
\end{tabular}

Table 2. Mean Scores of OSS for Health Personnel in FHCs and CHCs a,b

\begin{tabular}{lcccc}
\hline Subscales & Nurses & Physicians & Other Health Personnel & All Health Personnel \\
\hline S1. Occupational diseases and complaints & $2.88 \pm 1.3$ & $3.38 \pm 1.29$ & $3.14 \pm 1.24$ & $3.04 \pm 1.3$ \\
S2. Injuries and poisoning & $3.96 \pm 1.55$ & $4.36 \pm 1.41$ & $4.22 \pm 1.4$ & $4.09 \pm 1.5$ \\
S3. Health screening and registry systems & $2.65 \pm 1.43$ & $3.05 \pm 1.5$ & $2.77 \pm 1.36$ & $2.76 \pm 1.44$ \\
S4. Materials, tools and equipment control & $3.74 \pm 1.41$ & $4.27 \pm 1.33$ & $3.81 \pm 1.49$ & $3.87 \pm 1.42$ \\
S5. Physical medium compatibility & $4.34 \pm 1.35$ & $4.72 \pm 1.25$ & $4.18 \pm 1.3$ & $4.40 \pm 1.33$ \\
S6. Critical fields control & $2.89 \pm 1.62$ & $3.53 \pm 1.49$ & $3.39 \pm 1.66$ & $3.12 \pm 1.62$ \\
S7. Protective instructions and rules & $3.53 \pm 1.55$ & $4.03 \pm 1.44$ & $3.99 \pm 1.24$ & $3.73 \pm 1.49$ \\
Total & $3.43 \pm 0.97$ & $3.91 \pm 1.03$ & $3.64 \pm 0.87$ & $3.57 \pm 0.98$ \\
\hline
\end{tabular}

${ }^{a}$ Nurses, $n=418$; Physicians, $n=156$; other health personnel, $n=123$.

$\mathrm{b}$ All of the values are presented as Mean \pm SD. 
Ozturk H et al.

Table 3. Opinions of the Health Personnel Working at FHCs and CHCs on Occupational Accidents and Diseases a

\begin{tabular}{|c|c|c|c|}
\hline Opinions of Health Personnel & Nurse & Physician & Other Health Personnel \\
\hline \multicolumn{4}{|l|}{$\begin{array}{l}\text { Frequency of occupational accidents } \\
\text { or injuries at the center }\end{array}$} \\
\hline Often & $8(2)$ & - & $6(5)$ \\
\hline Frequent & $25(6)$ & $7(5)$ & $11(9)$ \\
\hline Medium & $83(20)$ & $8(5)$ & $31(25)$ \\
\hline Rarely & $221(53)$ & $98(63)$ & $57(46)$ \\
\hline Never observed & $81(19)$ & $43(28)$ & $18(15)$ \\
\hline Total & $418(100)$ & $156(100)$ & $123(100)$ \\
\hline \multicolumn{4}{|l|}{$\begin{array}{l}\text { Frequency of occupational disease at } \\
\text { the center }\end{array}$} \\
\hline Often & $8(2)$ & $2(1)$ & $10(8)$ \\
\hline Frequent & $22(5)$ & $8(5)$ & $17(14)$ \\
\hline Medium & $9(23)$ & $26(17)$ & $37(30)$ \\
\hline Rarely & $176(42)$ & $70(45)$ & $39(32)$ \\
\hline Never observed & $114(27)$ & $50(32)$ & $20(16)$ \\
\hline Total & $418(100)$ & $156(100)$ & $123(100)$ \\
\hline \multicolumn{4}{|l|}{ Experienced occupational injuries ${ }^{b}$} \\
\hline Soft tissue trauma & $110(26)$ & $15(10)$ & $46(37)$ \\
\hline $\begin{array}{l}\text { Verbal violence from patient and rela- } \\
\text { tives }\end{array}$ & $110(26)$ & $32(21)$ & $50(41)$ \\
\hline \multicolumn{4}{|l|}{ Experienced occupational diseases ${ }^{b}$} \\
\hline $\begin{array}{l}\text { Digestive system diseases such as ulcers, } \\
\text { colitis }\end{array}$ & $76(18)$ & $26(17)$ & $18(15)$ \\
\hline Muscle-joint diseases such as disk hernia & $44(11)$ & $16(10)$ & $44(36)$ \\
\hline
\end{tabular}

$\mathrm{a}$ All of the values are presented as No. (\%).
$\mathrm{b}$ More than one response was given.

Table 4. Satisfaction status of the Health Personnel Working at FHCs and CHCs on Activities Related to Occupational Safety ${ }^{\text {a }}$

\begin{tabular}{|c|c|c|c|c|c|c|}
\hline \multirow{2}{*}{$\begin{array}{l}\text { Activities regarding occupational } \\
\text { safety }\end{array}$} & \multicolumn{2}{|c|}{ Nurse } & \multicolumn{2}{|c|}{ Physician } & \multicolumn{2}{|c|}{ Other Health Personnel } \\
\hline & Satisfied & Not Satisfied & Satisfied & Not Satisfied & Satisfied & Not Satisfied \\
\hline Number of nurses & $212(51)$ & $206(49)$ & $44(28)$ & $112(72)$ & $58(47)$ & $65(53)$ \\
\hline Quality of cleaning materials & $205(49)$ & $213(51)$ & $130(83)$ & $26(17)$ & $51(42)$ & $72(59)$ \\
\hline $\begin{array}{l}\text { Health and safety policies for } \\
\text { personnel }\end{array}$ & $165(40)$ & $253(61)$ & $79(51)$ & $77(49)$ & $56(46)$ & $67(55)$ \\
\hline Personnel safety training & $164(39)$ & $254(61)$ & $63(40)$ & $93(60)$ & $43(35)$ & $80(65)$ \\
\hline $\begin{array}{l}\text { Undertaking and support } \\
\text { of the institution about an } \\
\text { occupational accident or disease }\end{array}$ & $158(38)$ & $260(62)$ & $60(39)$ & $96(62)$ & $41(33)$ & $82(67)$ \\
\hline
\end{tabular}

${ }^{\mathrm{a}}$ Data are presented as No.(\%) 
Ozturk H et al.

Table 5. Comparison of OSS Score Means of Health Personnel in FHCs and CHCs

\begin{tabular}{|c|c|c|c|c|}
\hline Subscales & Nurse $(n=418)$ & Physician $(n=156)$ & Other Health Personnel $(\mathrm{n}=123)$ & $\chi_{\mathrm{K}-\mathrm{W}}^{2}$ and F Values \\
\hline \multicolumn{5}{|l|}{ S1 } \\
\hline Mean Rank & 324.5 & 400.3 & 367.1 & $\chi_{\mathrm{K}-\mathrm{W}}^{2}=17.31^{\mathrm{a}}$ \\
\hline Median & 2.93 & 3.20 & 3.13 & \\
\hline IQR & 1.87 & 1.67 & 1.83 & \\
\hline \multicolumn{5}{|l|}{ S2 } \\
\hline Mean Rank & 331.6 & 384.5 & 363.0 & $\chi_{K-W}^{2}=8.59^{b}$ \\
\hline Median & 4.50 & 4.50 & 4.66 & \\
\hline IQR & 2.17 & 2.13 & 2.0 & \\
\hline \multicolumn{5}{|l|}{ S3 } \\
\hline Mean Rank & 332.4 & 388.4 & 355.3 & $\chi_{\mathrm{K}-\mathrm{W}}^{2}=8.99^{\mathrm{b}}$ \\
\hline Median & 3.33 & 3.16 & 3.16 & \\
\hline IQR & 3.0 & 2.5 & 2.33 & \\
\hline \multicolumn{5}{|l|}{ S4 } \\
\hline Mean Rank & 330.1 & 405.4 & 341.6 & $\chi^{2}{ }_{K-W}=16.14^{a}$ \\
\hline Median & 4.40 & 4.40 & 4.40 & \\
\hline IQR & 2.2 & 2.0 & 2.40 & \\
\hline \multicolumn{5}{|l|}{ S5 } \\
\hline Mean Rank & 341.4 & 399.1 & 399.1 & $\chi^{2}{ }_{K-W}=14.79^{a}$ \\
\hline Median & 5.00 & 4.75 & 4.75 & \\
\hline IQR & 2.0 & 2.15 & 2.0 & \\
\hline \multicolumn{5}{|l|}{ S6 } \\
\hline Mean Rank & 318.9 & 403.6 & 403.6 & $\chi^{2}{ }_{K-W}=24.33^{a}$ \\
\hline Median & 4.00 & 4.00 & 4.00 & \\
\hline IQR & 3.0 & 2.0 & 2.42 & \\
\hline \multicolumn{5}{|l|}{ S7 } \\
\hline Mean Rank & 323.9 & 389.5 & 389.5 & $\chi^{2}{ }_{K-W}=16.41^{a}$ \\
\hline Median & 4.33 & 4.00 & 4.16 & \\
\hline IQR & 2.33 & 2.0 & 2.08 & \\
\hline \multicolumn{5}{|l|}{ Total } \\
\hline Mean \pm SD & $3.43 \pm 0.97$ & $3.91 \pm 1.03$ & $3.91 \pm 1.03$ & $\mathrm{~F}=14.18^{\mathrm{a}}$ \\
\hline
\end{tabular}

\section{Discussion}

The purpose of community and family health centers is to improve, protect and develop the health of the community and individuals and to treat their non-serious diseases. While offering such services, health personnel experience health problems ranging from infectious diseases to violence, from burnout syndrome to radiationrelated cancers and repetitive traumas (21). All the healthcare personnel, including nurses, physicians, and others who participated in this study and worked at the family and community health centers explained that although some areas related to occupational safety were covered, significant issues such as health screening and registry systems, radiation, special area inspections regarding chemicals and infections were ignored. Furthermore, occupational safety in general was evaluated to be insufficient by nurses. The poor perception of the occupational safety by nurses might be due to the fact that the majority of them were women. Female nurses, in particular, stated that occupational safety was insufficient in injuries, accidents and poisoning, as well as in the protective instruction and rules. These findings demonstrated the insufficiency of protective and supportive activities associated with occupational safety at these centers.

The fact that more than half of nurses and other health- 
care personnel are dissatisfied with the institutional policies regarding occupational health and safety supported this idea. In fact, directors of healthcare organizations must establish policies to prevent occupational accidents and diseases. These protective policies should include the stages of making corporate-administrative provisions, follow-up, enlightenment, sensitization, and adaptation (21). However, the majority of healthcare personnel employed at these centers were not even aware of the "communique on patient and personnel safety," and also not satisfied with the training provided on the subject. It is therefore believed that education is insufficient at these centers. Nevertheless, the first step in studies on health protection is the dissemination of information (6). Accordingly, the importance of improving the awareness and quality of staff through in-service training is emphasized $(15,22-24)$. Additionally, a study conducted on occupational health and safety states the need for providing training on subjects such as the enlightenment of health personnel about defined risks and dangers, prevention and mitigation of exposure to and preparation for emergencies, use of personal protective equipment, notification of accidents and injuries, and so on (10). The same study points to the importance of medical examinations before starting to work and periodically while working, providing immunization, sufficient and balanced nutrition, and the need to treat injured or sick health personnel. Conducting inspections regarding infectious diseases and enlightenment of personnel, management, labor unions, and registry issues, health screening and research results were also emphasized in the same study (10). The findings of our study indicated that health screening and registry systems were insufficient. Another matter of complaint was the deficiency in the number of nurses. A study on nursing homes also found that staffing levels for registered nurses and nurse's aides were associated with injury rates (25). Another study conducted at community health centers stated that workloads increased at community health centers as a result of the multiple duties performed with a limited number of personnel (4). Workload intensity, at the same time, causes diseases such as musculoskeletal disorders and certain psychological problems (19). Other healthcare personnel, on the other hand, complained of the use of unqualified/hazardous cleaning materials that contain chemicals since these may be responsible for causing diseases such as asthma or allergic dermatitis $(24,26)$. The procurement therefore of non-hazardous cleaning materials may prevent such complaints or diseases. Insufficient protective and supportive activities related to occupational health and safety may result in increased complaints in institutions and the occurrence of injuries, accidents and diseases (23).

According to the findings of the present study, all health personnel, albeit rarely, were exposed to violence from patients and their relatives. In addition, nurses reported experiencing injuries due to soft tissue trauma. The situ- ation was the same for occupational diseases. However, digestive system diseases such as ulcers and colitis were the primary occupational diseases experienced by nurses and physicians whereas other health personnel complained more about muscle-joint diseases such as disk hernias. Results of some international and national studies also supported the findings of this study. These studies reported that verbal and physical violence (26-32), soft tissue trauma based on sharp/piercing tools, injuries, and infections associated with chemical and biological solid and liquid matter contamination (6, 11, 33-36), and complaints related to muscle-joint pains were observed, in particular $(2,6,26,37)$. In addition, musculoskeletal injuries in the healthcare setting may result from occurrences outside of patient's control, such as assaults, slipping, tripping $(2,38)$. However, it was stated that the visibility rate of some infections like HIV was lower at these centers $(11,39)$. Another study also determined typical occupational accidents at 12 levels, besides violence; 8 of these levels were related to piercing-cutting materials and biological fluids whereas the other 3 levels were related to socioenvironmental factors such as electric fences, dogs, horses, and poisonous animals encountered during home visits, while one was related to physical characteristics like the small scale of family health centers (11). All of these studies show that the health of medical staff is under threat and activities directed toward occupational safety in these centers remain insufficient.

In conclusion, health personnel working at community and family health centers, particularly nurses, have found insufficient the protective and supportive activities or applications related to occupational safety provided by their institutions. These insufficient activities or applications had primarily been defined for the following areas: the lack of informative and educational meetings; health screening and registry systems; specific areas that needed to be inspected periodically; noncompliance with protective directions, rules or policies; and non-compliance with regulations. However, occupational diseases of the digestive system and musculoskeletal system, occupational injuries such as soft-tissue trauma, and violence are observed due to insufficient occupational safety. Therefore, activities concerning occupational safety must be accelerated in order to meet regulations related to this subject and the requirements specific to these centers, protect the healthy workforce from avoidable health problems in their jobs, increase work performance, reduce the number of absence days, and not to victimize the personnel and his or her family. Moreover, some procedures such as health screening and examinations, establishment of registry systems, as well as the frequency of occupational accidents and diseases must be periodically monitored and controlled through mechanisms established within the scope of the ministry and local health authorities. Finally, security personnel should be hired to avoid cases of violence that may occur at these centers. 


\section{Acknowledgements}

We thank the Trabzon provincial Health Director of the Ministry of Health for giving support or permitting to do the study. In addition, we thank the health personnel who shared their ideas with us by participating in the study.

\section{Authors' Contributions}

Havva Ozturk developed the original idea and the protocol, collected, abstracted, and analyzed the data, wrote the manuscript, and was the guarantor. Elif Babacan contributed to the development of the protocol, collected and abstracted the data, and prepared the manuscript.

\section{References}

1. Barr J, Welch A. Keeping nurse researchers safe: workplace health and safety issues. JAdv Nurs. 2012;68(7):1538-45.

2. Tullar JM, Brewer S, Amick BC, 3rd, Irvin E, Mahood Q, Pompeii LA, et al. Occupational safety and health interventions to reduce musculoskeletal symptoms in the health care sector. J Occup Rehabil. 2010;20(2):199-219.

3. T C. Saglık Bakanlıgı Saglık İstatistikleri Yıllıgı 2008. In: T.C. editor. Refik Saydam Hifzıssihha Merkezi Baskanlıg Hifzıssıhha Mektebi Mudurlugu. Ankara/Turkey; 2010. p. 65.

4. Ay S, Güngör N, Özbasaran, F. Manisa il merkezindeki saglik ocaklarinda çalisan personelin iş doyumu. Hastane Yönetimi J. 2005:48-58.

5. Özkan Ö, Emiroğlu, N. Hastane sağlik çalișanlarina yönelik ișçi sağliği ve iș güvenliği hizmetleri. C.U. Hemșirelik Yüksekokulu Dergisi. 2006;10(3):43-51.

6. Ergör A, Kılıç B, Gürpınar E. Sağlık ocaklarında iş riskleri. Mesleki Sağllk ve Güvenlik Dergisi. 2003;16:44-50.

7. Michie S, Williams S. Reducing work related psychological ill health and sickness absence: a systematic literature review. Occup Environ Med. 2003;60(1):3-9.

8. Dollard M, La Montagne A, Caulfeild N, Blewett V, Shaw A. Job stresss in the Australian and International Health and Community Services Sector a review of literature. Inter J Stres Manag. 2007;14:417-45.

9. Dollard ME,, McTernan W. Psychosocial safety climate: a multilevel theory of work stresss in the health and community service sector. Epidemiol Psychiatric Sci. 2011;20(4):287-93.

10. LaMontagne AD, Keegel T, Vallance D, Ostry A, Wolfe R. Job-starin attributable depression in a sample of working Australians: Assessing the contribution to health inequalities. BMC Public Health. 2011;8:181-9.

11. Cezar-Vaz MR, Soares MR, Souza JF, Figueiredo Pd, Azambuja Ed, Sant'Anna CF. Risk perception in family health work: Study with workers in southern Brazil. Rev. Latino-Am. Enfermagem. 2009;17(6):961-7.

12. Evanoff B, Wolf L, Aton E, Canos Jc, ollins J. Reduction in injury rates in nursing personnel through introduction of mechanical lifts in the workplace. Americ J Industrial Medic. 2003;44:451-7.

13. Trinkoff AM, Johantgen M, Muntaner C, Le R. Staffing and worker injury in nursing homes. Am J Public Health. 2005;95(7):1220-5.

14. Waehrer G, Leigh JP, Miller TR. Costs of occupational injury and illness within the health services sector. Int J Health Serv. 2005;35(2):343-59.

15. Nisan. Hasta ve çahısan güvenliğinin sağlanmasına dair yönetmelik. 06 ed. Resmi Gazete, editor; 2009.

16. Öztürk H, Babacan E, Bayramoğlu, T. Trabzon aile ve toplum sağliği merkezlerinde çalișan sağlik personelinin iș güvenliği. III. Uluslararası Sağhkta Performans ve Kalite Kongresi Poster Bildiril- er Kitabı.Ankara: Sağlık Bakanlığı Tedavi Hizmetleri Genel Müdürlüğü; 2011. pp. 125-35.

17. Şencan, H. Sosyal ve Davranıșsal Ölçümlerde Güvenilirlik ve Geçerlilik.Ankara/Turkey: Seçkin Yayıncılık; 2005. pp. 113-114.

18. Buyukozturk S. Sosyal Bilimler Için Veri Analizi El Kitabı.Ankara/Turkey: Pegem Yayincilik; 2009. pp. 118-119-165.

19. Sipahi B, Yurtkoru ES, Cinko M. Sosyal Bilimlerde SPSS Ile Ver Analizi.Istanbul: Beta Bas; 2008.pp. 73-80, 81, 87, 89.

20. Altunıșık R, Çoşkun R, Bayraktaroğlu S, Yıldırım E. Sosyal Bilimlerde Araștirma Yöntemleri.Sakarya: Sakarya Yayıncılık; 2010. p. 115. 270-273.

21. Töz I, Gidener S, Ergör A, Demiral Y, Baydu RH. Hastane Ișletmelerinde Çahıșan Sağhğ̆ Örgütlenmesi ve Bir Uygulama Modeli, Ulusal Sağllk Kuruluşlan Yönetimi Kongresi Bilimsel Kitabı.İstanbul/ Turkey: Sağlık Yöneticileri Derneği;2007. pp. 98-101.

22. Bahcecik N, Ozturk H. The occupational safety and health in hospitals from the point of nurses. Coll Antropol. 2009;33(4):1205-14.

23. Khorshid L, Demir Y. Ergonomi ve hemșirelik. HastaneYönetimi. 2006;10(1):67-75.

24. Delcos GL, Gimeno D, Arif A. Occupational risk factors and asthma among health care professionals. Am J Respir Crit Care Med. 2007;175:667-75.

25. Castle NG, Engberg J, Mendeloff J, Burns R. A national view of workplace injuries in nursing homes. Health Care Manage Rev. 2009;34(1):92-103.

26. Saygun M. Sağlık çalıșanlarında iș sağlığı ve güvenliği sorunlar TAF Prev Med Bull. 2012;11(4):373-82.

27. Findorff MJ, McGovern PM, Wall MM, Gerberich SG. Reporting violence to a health care employer: a cross-sectional study. AAOHN J. 2005;53(9):399-406.

28. Nachreiner NM, Gerberich SG, Ryan AD, McGovern PM. Minnesota nurses' study: perceptions of violence and the work environment. Ind Health. 2007;45(5):672-8.

29. Lancman S, Ghirardi MI, Castro ED, Tuacek TA. Repercussions of violence on the mental health of workers of the Family Health Program. Rev Saude Publica. 2009;43(4):682-8.

30. El-Gilany AH, El-Wehady A, Amr M. Violence against primary health care workers in Al-Hassa, Saudi Arabia.J Interpers Violence. 2010;25(4):716-34.

31. Keser Özcan N, Bilgin H. Türkiye'de sağlık çalıșanlarına yönelik șiddet: Sistematik derleme. Türkiye Klinikleri J Med Sci. 2011;31:142-6.

32. Al B, Zengin S, Deryal Y, Gökçen C, Yılmaz, D. A., Yıldırım, C.. Increased violence towards health care staff. J Acad Emergenc Medic. 2012;11:115-24.

33. Chiodi MB, Marziale MH, Robazzi ML. Occupational accidents involving biological material among public health workers. Rev Lat Am Enfermagem. 2007;15(4):632-8.

34. Ayranci U, Kosgeroglu N. Needlestick and sharps injuries among nurses in the healthcare sector in a city of western Turkey.J Hosp Infect. 2004;58(3):216-23.

35. Garcia LP, Facchini LA. Exposures to blood and body fluids in Brazilian primary health care. Occup Med (Lond). 2009;59(2):107-13.

36. Gengo e Silva Rde C, Felli VE. [Comparative study on the identification of occupational risks for nursing workers at 2 basic health units of the municipality of Sao Paulo]. Rev Esc Enferm USP. 2002;36(1):18-24.

37. Collins JW, Wolf L, Bell J, Evanoff B. An evaluation of a "best practices" musculoskeletal injury prevention program in nursing homes. Inj Prev. 2004;10(4):206-11.

38. Craib KJ, Hackett G, Back C, Cvitkovich Y, Yassi A. Injury rates, predictors of workplace injuries, and results of an intervention program among community health workers. Public Health Nurs. 2007;24(2):121-31.

39. de Souza MC, Freitas MI. Representations of primary care professionals about the occupational risk of HIV infection. Rev Lat Am Enfermagem. 2010;18(4):748-54. 